\title{
The Generation of Postmemory
}

\author{
Marianne Hirsch \\ Columbia University
}

\begin{abstract}
Postmemory describes the relationship of the second generation to powerful, often traumatic, experiences that preceded their births but that were nevertheless transmitted to them so deeply as to seem to constitute memories in their own right. Focusing on the remembrance of the Holocaust, this essay elucidates the generation of postmemory and its reliance on photography as a primary medium of transgenerational transmission of trauma. Identifying tropes that most potently mobilize the work of postmemory, it examines the role of the family as a space of transmission and the function of gender as an idiom of remembrance.
\end{abstract}

The guardianship of the Holocaust is being passed on to us. The second generation is the hinge generation in which received, transferred knowledge of events is being transmuted into history, or into myth. It is also the generation in which we can think about certain questions arising from the Shoah with a sense of living connection.

Eva Hoffman, After Such Knowledge

\section{The Postgeneration}

The "hinge generation," the "guardianship of the Holocaust," the ways in which "received, transferred knowledge of events is being transmuted into history, or into myth" (Hoffman 2004: xv) - these, indeed, have been

I am grateful to audiences at the Midwest Modern Language Association, Columbia, Leeds, and Duke Universities, where I delivered earlier versions of this essay. Thanks as well to Silke Horstkotte, Irene Kacandes, Alice Kessler-Harris, Nancy K. Miller, Nancy Pedri, Leo Spitzer, Meir Sternberg, and Gary Weissman for invaluable questions and suggestions.

Poetics Today 29:1 (Spring 2008) DOI 10.1215/o3335372-2007-019

(C) 2008 by Porter Institute for Poetics and Semiotics 
my preoccupations for the last decade and a half. I have been involved in a series of conversations about how that "sense of living connection" can be, and is being, maintained and perpetuated even as the generation of survivors leaves our midst and how, at the very same time, it is being eroded. For me, the conversations that have marked what Eva Hoffman (ibid.: 203) calls the "era of memory" have had some of the intellectual excitement and the personal urgency, even some of the sense of community and commonality of the feminist conversations of the late 1970 and the 1980s. And they have been punctured as well by similar kinds of controversies, disagreements, and painful divisions. At stake is precisely the "guardianship" of a traumatic personal and generational past with which some of us have a "living connection" and that past's passing into history. At stake is not only a personal/familial/generational sense of ownership and protectiveness but also an evolving theoretical discussion about the workings of trauma, memory, and intergenerational acts of transfer, a discussion actively taking place in numerous important contexts outside of Holocaust studies. ${ }^{1}$ More urgently and passionately, those of us working on memory and transmission have argued over the ethics and the aesthetics of remembrance in the aftermath of catastrophe. How, in our present, do we regard and recall what Susan Sontag (2003) has so powerfully described as the "pain of others?" What do we owe the victims? How can we best carry their stories forward without appropriating them, without unduly calling attention to ourselves, and without, in turn, having our own stories displaced by them? How are we implicated in the crimes? Can the memory of genocide be transformed into action and resistance?

The multiplication of genocides and collective catastrophes at the end of the twentieth century and the beginning of the twenty-first, and their cumulative effects, have made these questions ever more urgent. The bodily, psychic, and affective impact of trauma and its aftermath, the ways in which one trauma can recall, or reactivate, the effects of another, exceed the bounds of traditional historical archives and methodologies. Late in his career, for example, Raul Hilberg (1985), after combing through miles of documents and writing his massive thirteen hundred-page book The Destruction of the European Fews - and, indeed, after dismissing oral history and testimony for its inaccuracies of fact-deferred to storytelling as a skill historians need to learn if they are to be able to tell the difficult his-

1. On the notion of generation, see especially Suleiman 2002 and Weigel 2002. Other contexts besides the Holocaust and the Second World War in which intergenerational transmission has become an important explanatory vehicle and object of study include American slavery, the Vietnam War, the Dirty War in Argentina, South African apartheid, Soviet and East European communist terror, and the Armenian and the Cambodian genocides. 
tory of the destruction of the Jews (Lang 1988: 273). Hilberg is recalling a dichotomy between history and memory (for him, embodied by poetry and narrative) that has had a shaping effect. But fifty years after Adorno's contradictory injunctions about poetry after Auschwitz, poetry is now only one of many supplemental genres and institutions of transmission. The now numerous and better-funded testimony projects and oral history archives, the important role assumed by photography and performance, the evergrowing culture of memorials, and the new museology - all are testaments to the need for aesthetic and institutional structures that might be able to account for what Diana Taylor (2003) calls "the repertoire" of embodied knowledge absent from the historical archive (or perhaps merely neglected by traditional historians). For better or worse, these supplemental genres and institutions have been grouped under the umbrella term "memory." But as Andreas Huyssen (2003: 6) has provocatively asked, "What good is the memory archive? How can it deliver what history alone no longer seems to be able to offer?" 2

If "memory" as such a capacious analytic term and "memory studies" as a field of inquiry have grown exponentially in academic and popular importance in the last decade and a half, they have, in large part, been fueled by the limit case of the Holocaust and by the work of (and about) what has come to be known as "the second generation" or "the generation after." "Second generation" writers and artists have been publishing artworks, films, novels, and memoirs, or hybrid "postmemoirs" (as Leslie Morris [2002] has dubbed them), with titles like "After Such Knowledge," "The War After," "Second-Hand Smoke," "War Story," "Lessons of Darkness," "Losing the Dead," "Dark Lullabies," "Fifty Years of Silence," "After," "Daddy's War," as well as scholarly essays and collections like "Children of the Holocaust," "Daughters of the Shoah," "Shaping Losses," "Memorial Candles," "In the Shadow of the Holocaust," and so on. The particular relation to a parental past described, evoked, and analyzed in these works has come to be seen as a "syndrome" of belatedness or "post-ness" and has been variously termed "absent memory" (Fine 1988), "inherited memory," "belated memory," "prosthetic memory" (Lury 1998, Landsberg 2004), "mémoire trouée" (Raczymow 1994), "mémoire des cendres" (Fresco 1984), "vicarious witnessing" (Zeitlin 1998), "received history" (Young 1997), and "postmemory." These terms reveal a number of controversial assumptions: that descendants of survivors (of victims as well as of perpetrators) of massive traumatic events connect so deeply to

2. For a critical take on the current surfeit of memory, see especially Huyssen 2003 and Robin 2003. 
the previous generation's remembrances of the past that they need to call that connection memory and thus that, in certain extreme circumstances, memory can be transmitted to those who were not actually there to live an event. At the same time-so it is assumed-this received memory is distinct from the recall of contemporary witnesses and participants. Hence the insistence on "post" or "after" and the many qualifying adjectives that try to define both a specifically inter- and trans-generational act of transfer and the resonant aftereffects of trauma. If this sounds like a contradiction, it is, indeed, one, and I believe it is inherent to this phenomenon.

Postmemory is the term I came to on the basis of my autobiographical readings of works by second generation writers and visual artists. ${ }^{3}$ The "post" in "postmemory" signals more than a temporal delay and more than a location in an aftermath. Postmodern, for example, inscribes both a critical distance and a profound interrelation with the modern; postcolonial does not mean the end of the colonial but its troubling continuity, though, in contrast, postfeminist has been used to mark a sequel to feminism. We certainly are, still, in the era of "posts," which continue to proliferate: "post-secular," "post-human," "postcolony," "post-white." Postmemory shares the layering of these other "posts" and their belatedness, aligning itself with the practice of citation and mediation that characterize them, marking a particular end-of-century/turn-of-century moment of looking backward rather than ahead and of defining the present in relation to a troubled past rather than initiating new paradigms. Like them, it reflects an uneasy oscillation between continuity and rupture. And yet postmemory is not a movement, method, or idea; I see it, rather, as a structure of inter- and trans-generational transmission of traumatic knowledge and experience. It is a consequence of traumatic recall but (unlike posttraumatic stress disorder) at a generational remove.

As Hoffman (2004: 25) writes: "The paradoxes of indirect knowledge haunt many of us who came after. The formative events of the twentieth century have crucially informed our biographies, threatening sometimes to overshadow and overwhelm our own lives. But we did not see them, suffer through them, experience their impact directly. Our relationship to them has been defined by our very 'post-ness' and by the powerful but mediated forms of knowledge that have followed from it." Postmemory describes the relationship that the generation after those who witnessed cultural or collective trauma bears to the experiences of those who came before, experiences that they "remember" only by means of the stories, images, and behaviors among which they grew up. But these experiences

3. On "autobiographical reading" see Suleiman 1993. 
were transmitted to them so deeply and affectively as to seem to constitute memories in their own right. Postmemory's connection to the past is thus not actually mediated by recall but by imaginative investment, projection, and creation. To grow up with such overwhelming inherited memories, to be dominated by narratives that preceded one's birth or one's consciousness, is to risk having one's own stories and experiences displaced, even evacuated, by those of a previous generation. It is to be shaped, however indirectly, by traumatic events that still defy narrative reconstruction and exceed comprehension. These events happened in the past, but their effects continue into the present. This is, I believe, the experience of postmemory and the process of its generation.

I realize that my description of this structure of inter- and transgenerational transmission of trauma raises as many questions as it answers. Why insist on the term memory to describe this structure of transmission? Is postmemory limited to the intimate embodied space of the family, or can it extend to more distant, adoptive witnesses? Is postmemory limited to victims, or does it include bystanders and perpetrators, or could one argue that it complicates the delineations of these positions which, in Holocaust studies, have come to be taken for granted? What aesthetic and institutional structures, what tropes, best mediate the psychology of postmemory, the connections and discontinuities between generations, the gaps in knowledge that define the aftermath of trauma? And how has photography in particular come to play such an important role in this process of mediation?

For me, it was the three photographs intercalated in Art Spiegelman's Maus that first elicited the need for a term that would describe the particular form of belated or inherited memory that I found in Spiegelman's work (Hirsch 1992-93). Indeed, the phenomenology of photography is a crucial element in my conception of postmemory as it relates to the Holocaust in particular. ${ }^{4}$ To be sure, the history of the Holocaust has come down to us, in subsequent generations, through a vast number of photographic images meticulously taken by perpetrators eager to record their actions and also by bystanders and, often clandestinely, by victims. But it is the technology of photography itself, and the belief in reference it engenders, that connects the Holocaust generation to the generation after. Photography's promise to offer an access to the event itself, and its easy assumption of iconic and symbolic power, makes it a uniquely powerful medium for

4. See also the work of art historian Andrea Liss (1998: 86), who, around the same time, used the term "postmemories" in a more circumscribed way to describe the effects that some of the most difficult Holocaust photographs have had on what she termed the "post-Auschwitz generation." 
the transmission of events that remain unimaginable. And, of course, the photographic meaning of generation captures something of the sequencing and the loss of sharpness and focus inherent in postmemory.

As memory studies have become an interdisciplinary, or post-disciplinary, formation par excellence, the site where historians, psychoanalysts, sociologists, philosophers, ethicists, scholars of religion, artists and art historians, writers and literary scholars can think, work, and argue together, it seems a good moment to scrutinize some basic assumptions. In doing so in this essay, I propose to use the Holocaust as my historical frame of reference, but my analysis relies on and, I believe, is relevant to numerous other contexts of traumatic transfer that can be understood as postmemory.

In what follows, I will look critically, and from a feminist perspective, at the conjunction of three powerful and prevalent elements of the trans-generational structure of postmemory in the aftermath of the Second World War-memory, family, and photography. I will analyze one trope in particular: the trope of maternal abandonment and the fantasy of maternal recognition which is pervasive in Holocaust remembrance. I use this trope to show how postmemory risks falling back on familiar, and unexamined, cultural images that facilitate its generation by tapping into what Aby Warburg saw as a broad cultural "storehouse of pre-established expressive forms" in what he called the "iconology of the interval," the "space between thought and the deepest emotional impulses" (see Fleckner and Sarkis 1998: 252; Pollock 2005: 6; Didi-Huberman 2003b). For the post-Holocaust generation, these "pre-established" forms in large part take the shape of photographs - images of murder and atrocity, images of bare survival, and also images of "before" that signal the deep loss of safety in the world. As "pre-established" and well-rehearsed forms prevalent in postmemorial writing, art, and display, some of these photographic images illustrate particularly well how gender can become a potent and troubling idiom of remembrance for the postgeneration and suggest one way in which we might theorize the relationship between memory and gender.

\section{Why Memory?}

"We who came after do not have memories of the Holocaust," writes Eva Hoffman (2004: 6) as she describes this "deeply internalized but strangely unknown past." She insists on being precise: "Even from my intimate proximity I could not form 'memories' of the Shoah or take my parents' memories as my own" (ibid.). In his recent book Fantasies of Witnessing (2004: 17), 
Gary Weissman objects specifically to the "memory" in my formulation of postmemory, arguing that "no degree of power or monumentality can transform one person's lived memories into another's." Both Weissman and Ernst van Alphen refer back to Helen Epstein's Children of the Holocaust (1979) to locate the beginnings of the current use of the notion of "memory" in the late 1980s and the 1990s: in contrast, they indicate, Epstein had described the "children of the Holocaust" as "possessed by a history they had never lived," and she did not use the term "second generation," which, van Alphen observes, implies too close a continuity between generations that are, precisely, separated by the trauma of the Holocaust. Epstein spoke of the "sons and daughters of survivors." Objecting to the term "memory" from a semiotic perspective, van Alphen (2006: 485, 486) firmly asserts that trauma cannot be transmitted between generations: "The normal trajectory of memory is fundamentally indexical," he argues. "There is continuity between the event and its memory. And this continuity has an unambiguous direction: the event is the beginning, the memory is the result. . . In the case of the children of survivors, the indexical relationship that defines memory has never existed. Their relationship to the past events is based on fundamentally different semiotic principles."

Nothing could be truer or more accurate: of course we do not have literal "memories" of others' experiences, of course different semiotic principles are at work, of course no degree of monumentality can transform one person's lived memories into another's. Postmemory is not identical to memory: it is "post," but at the same time, it approximates memory in its affective force. Hoffman (2004: 6, 9) describes what was passed down to her thus: "Rather, I took in that first information as a sort of fairy tale deriving not so much from another world as from the center of the cosmos: an enigmatic but real fairy tale. . . The memories - not memories but emanations - of wartime experiences kept erupting in flashes of imagery; in abrupt but broken refrains." These "not memories" communicated in "flashes of imagery" and "broken refrains," transmitted through "the language of the body," are precisely the stuff of postmemory.

Jan and Aleida Assmann's work on the transmission of memory clarifies precisely what Hoffman refers to as the "living connection" between proximate generations and thus account for the complex lines of transmission encompassed in the inter- and trans-generational umbrella term "memory." Both scholars have devoted themselves to elucidating, systematically, Maurice Halbwachs's (1992) enormously influential notion of collective memory. I turn to their work here to elucidate the lines of transmission between individual and collective remembrance and to specify how 
the break in transmission resulting from traumatic historical events necessitates forms of remembrance that reconnect and reembody an intergenerational memorial fabric that has been severed by catastrophe.

In his book Das kulturelle Gedächtnis (1997), Jan Assmann distinguishes between two kinds of collective remembrance, "communicative" memory and what he calls "cultural" memory. ${ }^{5}$ Communicative memory is "biographical" and "factual" and is located within a generation of contemporaries who witness an event as adults and who can pass on their bodily and affective connection to that event to their descendants. In the normal succession of generations (and the family is a crucial unit of transmission for Jan Assmann), this embodied form of memory is transmitted across three to four generations - across eighty to one hundred years. At the same time, as its direct bearers enter old age, they increasingly wish to institutionalize memory, whether in traditional archives or books or through ritual, commemoration, or performance. Jan Assmann terms this institutionalized archival memory "kulturelles Gedächtnis."

In her recent elaboration of this typology, Aleida Assmann (2006) extends this bimodal distinction into four memory "formats": the first two, individual memory and family/group memory, correspond to Jan Assmann's "communicative" remembrance, while national/political memory and cultural/archival memory form part of his "cultural" memory. A fundamental assumption driving this schema is, indeed, that "memories are linked between individuals." "Once verbalized," she insists, "the individual's memories are fused with the inter-subjective symbolic system of language and are, strictly speaking, no longer a purely exclusive and unalienable property. . . . they can be exchanged, shared, corroborated, confirmed, corrected, disputed - and, last not least, written down" (ibid.: 3). And even individual memory "include[s] much more than we, as individuals, have ourselves experienced" (ibid.: 10). Individuals are part of social groups with shared belief systems that frame memories and shape them into narratives and scenarios. For Aleida Assmann, the family is a privileged site of memorial transmission. The "group memory" in her schema is based on the familial transfer of embodied experience to the next generation: it is intergenerational. National/political and cultural/archival memory, in contrast, are not inter- but trans-generational; they are no longer mediated through embodied practice but solely through symbolic systems.

5. Assmann uses the term "kulturelles Gedächtnis" ("cultural memory") to refer to "Kultur" - an institutionalized hegemonic archival memory. In contrast, the AngloAmerican meaning of "cultural memory" refers to the social memory of a specific group or subculture. 
Jan and Aleida Assmann's typological distinctions do not specifically account for the ruptures introduced by collective historical trauma, by war, Holocaust, exile, and refugeehood: these ruptures would certainly inflect their schemas of transmission. Both embodied communicative memory and institutionalized cultural/archival memory would be severely impaired by traumatic experience. Within the space of the family or proximate group, survivors, as Hoffman (2004: 9) indicates, express not exactly "memories" but "emanations" in "a chaos of emotion." These typologies would also be compromised by the erasures of records, such as those perpetrated by totalitarian regimes. Under the Nazis, cultural archives were destroyed, records burned, possessions lost, histories suppressed and eradicated.

The structure of postmemory clarifies how the multiple ruptures and radical breaks introduced by trauma and catastrophe inflect intra-, inter- and trans-generational inheritance. It breaks through and complicates the line the Assmanns draw connecting individual to family, to social group, to institutionalized historical archive. That archive, in the case of traumatic interruption, exile, and diaspora, has lost its direct link to the past, has forfeited the embodied connections that forge community and society. And yet the Assmanns' typology explains why and how the postgeneration could and does work to counteract this loss. Postmemorial work, I want to suggest - and this is the central point of my argument in this essay-strives to reactivate and reembody more distant social/national and archival/cultural memorial structures by reinvesting them with resonant individual and familial forms of mediation and aesthetic expression. Thus less-directly affected participants can become engaged in the generation of postmemory, which can thus persist even after all participants and even their familial descendants are gone.

It is this presence of embodied experience in the process of transmission that is best described by the notion of memory as opposed to history and best mediated by photographic images. Memory signals an affective link to the past, a sense precisely of an embodied "living connection." Through the indexical link that joins the photograph to its subject-what Roland Barthes (1981: 8o) calls the "umbilical cord" made of light-photography, as I will show in more detail below, can appear to solidify the tenuous bonds that are shaped by need, desire, and narrative projection.

The growth of the memory culture may, indeed, be a symptom of a need for inclusion in a collective membrane forged by a shared inheritance of multiple traumatic histories and the individual and social responsibility we feel toward a persistent and traumatic past - what the French have referred to as "le devoir de mémoire." 


\section{Why the Family?}

"But they also spoke," Eva Hoffmann (2004: 9, 10) writes, denying that survivors were "wrapped in silence" - "how could they help it? - to their immediate intimates, to spouses and siblings, and, yes, to their children. There they spoke in the language of family-a form of expression that is both more direct and more ruthless than social and public speech. . . . In my home, as in so many others, the past broke through in the sounds of nightmares, the idioms of sighs and illness, of tears and acute aches that were the legacy of the damp attic and of the conditions my parents endured during their hiding."

The language of family, the language of the body: nonverbal and noncognitive acts of transfer occur most clearly within a familial space, often in the form of symptoms. It is perhaps the descriptions of this symptomatology that have made it appear as though the postgeneration wanted to assert its own victimhood alongside that of the parents.

To be sure, children of those directly affected by collective trauma inherit a horrific, unknown, and unknowable past that their parents were not meant to survive. Second generation fiction, art, memoir, and testimony are shaped by the attempt to represent the long-term effects of living in close proximity to the pain, depression, and dissociation of persons who have witnessed and survived massive historical trauma. They are shaped by the child's confusion and responsibility, by the desire to repair, and by the consciousness that the child's own existence may well be a form of compensation for unspeakable loss. Loss of family, of home, of a feeling of belonging and safety in the world "bleed" from one generation to the next, as Art Spiegelman so aptly put it in his subtitle to Maus I, "My father bleeds history."

And yet the scholarly and artistic work of these descendants also makes clear that even the most intimate familial knowledge of the past is mediated by broadly available public images and narratives. In the image in figure 1 , for example, from the 1972 three-page "The First Maus," the son can imagine his father's experience in Auschwitz only by way of a widely available photograph by Margaret Bourke-White of liberated prisoners in Buchenwald. The photo corners at the edges of Spiegelman's drawing show how this public image has been adopted into the family album, and the arrow pointing to "Poppa" shows how the language of family can literally reactivate and reembody a "cultural/archival" image whose subjects are, to most viewers, anonymous. This "adoption" of public, anonymous images into the family photo album finds its counterpart in the pervasive use of private, familial images and objects in institutions of public display-museums 


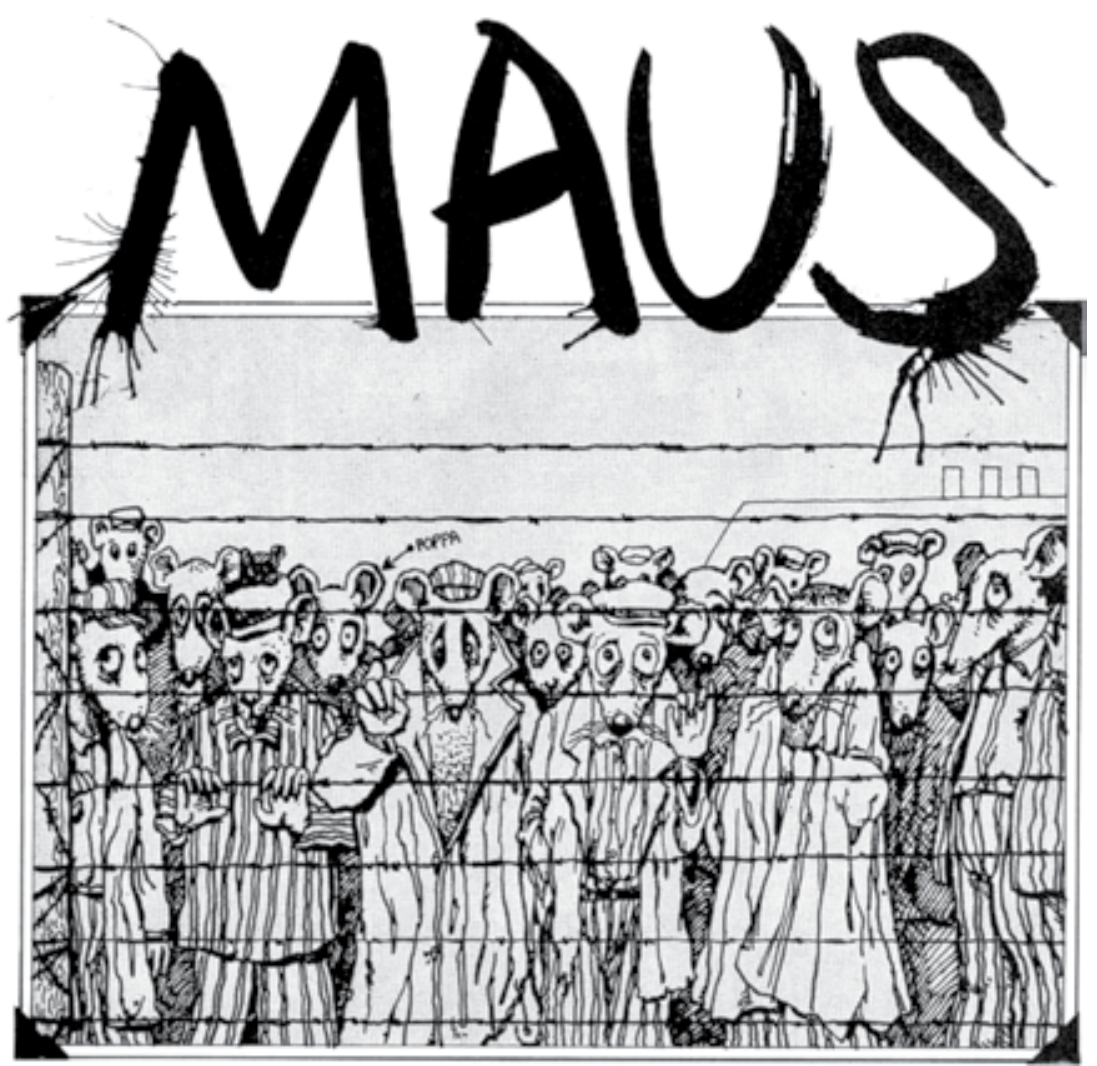

Figure 1 This image, from "The First Maus" (1972), in which Spiegelman can imagine his father's experience in Auschwitz only by reference to the widely circulated photograph by Margaret Bourke-White of liberated prisoners in Buchenwald, shows how this public image was adopted into the family album. From Spiegelman 2006 [1972]: 41.

and memorials like the Tower of Faces in the U.S. Holocaust Memorial Museum or certain exhibits in the Museum of Jewish Heritage in New York - which thus construct every visitor as a familial subject. This fluidity (some might call it obfuscation) is made possible by the power of the idea of family, by the pervasiveness of the familial gaze, and by the forms of mutual recognition that define family images and narratives. ${ }^{6}$

Even though, for those of us in the literal second generation, "our own internal imagery is powerful," as Hoffman (2004: 193) writes, and linked to the particular experiences communicated by our parents, other images

6. On the familial gaze, see Hirsch 1997 and 1998. 
and stories, especially those public images related to the concentration and extermination camps, "become part of [our] inner storehouse" (ibid.). When I referred to myself as a "child of survivors" in my writings on memory and postmemory, for example, it never occurred to me that my readers would assume, as Weissman (2004: 16, 17) has done in his book, that they were Auschwitz survivors. I would argue that, as public and private images and stories blend, distinctions and specificities between them are more difficult to maintain, and the more difficult they are to maintain, the more some of us might wish to reassert them so as to insist on the distinctiveness of a specifically familial second-generation identity. ${ }^{7}$

In my own writing, however, I have argued that postmemory is not an identity position but a generational structure of transmission deeply embedded in such forms of mediation. Family life, even in its most intimate moments, is entrenched in a collective imaginary shaped by public, generational structures of fantasy and projection and by a shared archive of stories and images that inflect the transmission of individual and familial remembrance. Geoffrey Hartman's (1996: 9) notion of "witnesses by adoption" and Ross Chambers's (2004: 199ff.) term "foster writing" acknowledge a break in biological transmission even as they preserve the familial frame. If we thus adopt the traumatic experiences of others as experiences that we might ourselves have lived through, if we inscribe them into our own life story, can we do so without imitating or unduly appropriating them? ${ }^{8}$ And is this process of identification, imagination, and projection radically different for those who grew up in survivor families and for those less proximate members of their generation or relational network who share a legacy of trauma and thus the curiosity, the urgency, the frustrated need to know about a traumatic past? Hoffman (2004: 187) draws a line, however tenuous and permeable, between "the postgeneration as a whole and the literal second generation in particular" (emphasis added). To delineate the border between these respective structures of transmission-between what I would like to refer to as familial and as "affiliative" postmemory ${ }^{9}$ we would have to account for the difference between an intergenerational vertical identification of child and parent occurring within the family and the intra-generational horizontal identification that makes that child's

7. See Bos 2003 for a series of distinctions between familial and nonfamilial aspects of postmemory and Bukiet 2002 for a strictly literal interpretation of the second generation.

8. See Hirsch 1998 for a theorization of non-appropriative identification based on Kaja Silverman's (1996) distinction between idiopathic and heteropathic identification.

9. It is useful, in this regard, to recall Edward Said's (1983) distinction between vertical filiation and horizontal affiliation, a term that acknowledges the breaks in authorial transmission that challenge authority and direct transfer. 
position more broadly available to other contemporaries. Affiliative postmemory would thus be the result of contemporaneity and generational connection with the literal second generation combined with structures of mediation that would be broadly appropriable, available, and indeed, compelling enough to encompass a larger collective in an organic web of transmission.

Familial structures of mediation and representation facilitate the affiliative acts of the postgeneration. The idiom of family can become an accessible lingua franca easing identification and projection across distance and difference. This explains the pervasiveness of family pictures and family narratives as artistic media in the aftermath of trauma. Still, the very accessibility of familial idioms needs also to engender suspicion on our part: does not locating trauma in the space of family personalize and individualize it too much? Does it not risk occluding a public historical context and responsibility, blurring significant differences-national difference, for example, or differences among the descendants of victims, perpetrators, and bystanders? (see McGlothlin 2006). Constructing the processes of transmission, and the postgeneration itself, in familial terms is as engaging as it is troubling. My aim in this essay is precisely to expose the attractions and the pitfalls of familial transmission.

\section{Why Photographs?}

For me, the key role of the photographic image-and of family photographs in particular - as a medium of postmemory clarifies the connection between familial and affiliative postmemory and the mechanisms by which public archives and institutions have been able both to reembody and to reindividualize "cultural/archival" memory. More than oral or written narratives, photographic images that survive massive devastation and outlive their subjects and owners function as ghostly revenants from an irretrievably lost past world. They enable us, in the present, not only to see and to touch that past but also to try to reanimate it by undoing the finality of the photographic "take." ${ }^{10}$ The retrospective irony of every photograph, made more poignant if violent death separates its two presents, consists precisely in the simultaneity of this effort and the consciousness of its impossibility.

In C. S. Peirce's tripartite definition of the sign, photographic images are more than purely indexical or contiguous to the object in front of the lens: they are also iconic, exhibiting a mimetic similarity to that object.

10. See especially Sontag 1989 and Barthes 1981 on the relationship of photography and death. 
Combining these two semiotic principles also enables them, quickly, and perhaps too easily, to assume symbolic status, and thus, in spite of the vast archive of images that the second generation has inherited, a small number of specific images, or kinds of images, have shaped our conception of the event and its transmission. ${ }^{11}$ The power of the intercalated photos in Maus can serve as illustration: the images of Anja and Richieu function as specters reanimating their dead subjects with indexical and iconic force. The photograph of Vladek in his concentration camp uniform, of Anja with her son, of Richieu as a young boy together reassemble a family destroyed by the Holocaust and consequently fractured in the artist's stylized drawings of mice and cats. They not only refer to their subjects and bring them back in their full appearance, but they also symbolize the sense of family, safety, and continuity that has been hopelessly severed.

Whether family pictures of a destroyed world or records of the process of its destruction, Holocaust photographs are the fragmentary remnants that shape the cultural work of postmemory. The work that they have been mobilized to do for the second generation, in particular, ranges from the indexical to the symbolic, and it is precisely their slippage within this range that needs to be scrutinized. In his controversial recent book Images malgré tout (2003a), the French art historian Georges Didi-Huberman describes the double regime of the photographic image. In it, he argues, we simultaneously find truth and obscurity, exactitude and simulacrum. Historical photographs from a traumatic past authenticate the past's existence, what Roland Barthes calls its "ça a été" or "having-been-there," and, in their flat two-dimensionality, they also signal its insurmountable distance and "derealization" (ibid.: 111). Unlike public images or images of atrocity, however, family photos, and the familial aspects of postmemory, would tend to diminish distance, bridge separation, and facilitate identification and affiliation. When we look at photographic images from a lost past world, especially one that has been annihilated by force, we look not only for information or confirmation, but also for an intimate material and affective connection. We look to be shocked (Benjamin), touched, wounded, and pricked (Barthes's punctum), torn apart (Didi-Huberman), and photographs thus become screens - spaces of projection and approximation and

11. Certainly witness testimony is an equally pervasive genre transmitting the memory of the Holocaust. But, I would argue, the technology of photography, with its semiotic principles, makes it a more powerful and also a more problematic vehicle for the generations after. The technologies recording witness testimony, the tape recorder and the video camera, share the promises and the frustrations embodied by the still camera and the photographic images that are its products. 
of protection. ${ }^{12}$ Small, two-dimensional, delimited by their frames, photographs minimize the disaster they depict and screen their viewers from it. But in seeming to open a window to the past and materializing the viewer's relationship to it, they also give a glimpse of its enormity and its power. They can tell us as much about our own needs and desires (as readers and spectators) as they can about the past world they presumably depict. While authentication and projection can work against each other, the powerful tropes of familiality can also, and sometimes problematically, obscure their distinction. The fragmentariness and the two-dimensional flatness of the photographic image, moreover, make it especially open to narrative elaboration and embroidery and to symbolization. ${ }^{13}$

What is more, we could argue that, in Paul Connerton's (1989) useful terms, photography is an "inscriptive" (archival) memorial practice that retains an "incorporative" (embodied) dimension: as archival documents that inscribe aspects of the past, photographs give rise to certain bodily acts of looking and certain conventions of seeing and understanding that we have come to take for granted but that shape and seemingly reembody, render material the past that we are seeking to understand and receive. And sight, Jill Bennett (2005: 36) has argued, is deeply connected to "affective memory": "images have the capacity to address the spectator's own bodily memory; to touch the viewer who feels rather than simply sees the event, drawn into the image through a process of affective contagion. ... Bodily response thus precedes the inscription of narrative, or moral emotion of empathy."

Two images (figure 2), drawn from Spiegelman's Maus (1987) and W. G. Sebald's Austerlitz (2001) will serve to illustrate this performative regime of the photograph and the gazes of familial and affiliative postmemory.

\section{Why Sebald?}

The cultural postmemory work that Art Spiegelman and Maus did in the late 1980 /early 1990 os is what the recently deceased German writer W. G. Sebald, and particularly his novel Austerlitz, is doing now, in the first decade of the new millennium. Both works have spawned a veritable industry of critical and theoretical work on memory, photography, and transmission, and thus the differences between Maus and Austerlitz are a measure of the evolving conversations of and about the postgeneration. My comparative

12. For the relationship of visuality to trauma, see especially Hüppauf 1997; Zelizer 1998; Baer 2002; Hornstein and Jacobowitz 2002; Bennett 2005; and van Alphen 2005. 13. See Horstkotte 2003 for a discussion of this aspect of photography and postmemory. 

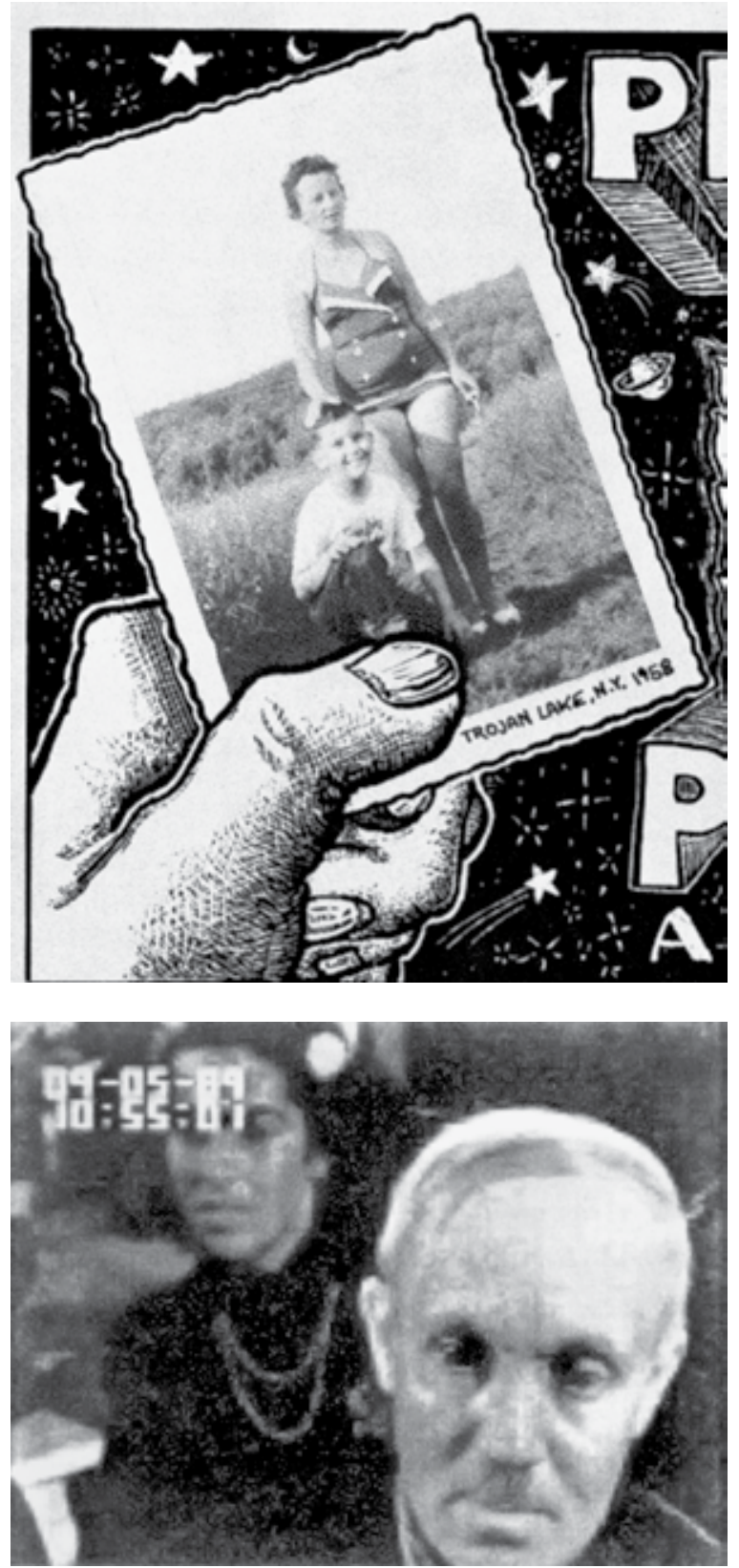

Figure 2 These two images, from Spiegelman's Maus (1987: 100) (above) and Sebald's Austerlitz (2001: 251), illustrate the performative regime of the photograph and the gazes of familial and affiliative postmemory. 
discussion here aims to bring out some of the elements implicit in these conversations - the continuing power of the familial and the indexical and, at the same time, a less literal, much more fluid conception of both that characterizes our turn-of-the-century remembrance and is illustrated by Sebald.

Maus and Austerlitz share a great deal: a self-conscious, innovative, and critical aesthetic that palpably conveys absence and loss; the determination to know about the past and the acknowledgment of its elusiveness; the testimonial structure of listener and witness separated by relative proximity and distance to the events of the war (two men in both works); the reliance on looking and reading, on visual media in addition to verbal ones; and the consciousness that the memory of the past is an act firmly located in the present. Still, the two authors could not be more different: one the son of two Auschwitz survivors, a cartoonist who grew up in the United States; the other a son of Germans, a literary scholar and novelist writing in England.

The narrators of Maus are father and son, first and second generations, and their conversations illustrate how familial postmemory works through the transformations and mediations from the father's memory to the son's postmemory. The generational structure of Austerlitz and its particular kind of postmemory is more complicated. Sebald himself, born in 1944, belongs to the second generation, but through his character Austerlitz, born in 1934 and a member of what Susan Suleiman (2002) terms the "1.5 generation," he blurs generational boundaries and highlights the current interest in the persona of the child survivor. Austerlitz himself has no memory of his childhood in Prague, which was erased and superseded by the new identity he was given when he arrived in Wales and was raised by Welsh adoptive parents. The conversations in the novel are intragenerational, between the narrator and the protagonist, both of whom (we assume) were young children during the war, one a non-Jewish German living in England, the other a Czech Jew. For them, the past is located in objects, images, and documents, in fragments and traces barely noticeable in the layered train stations, streets, and official and private buildings of the European cities in which they meet and talk. Standing outside the family, the narrator receives the story from Austerlitz and affiliates with it, thus illustrating the relationship between familial and affiliative postmemory. And as a German, he also shows how the lines of affiliation can cross the divide between victim and perpetrator postmemory.

Maus, while trenchantly critical of representation and eager to foreground its artifice, remains, at the same time, anxious about the truth and 
accuracy of the son's graphic account of the father's prewar and wartime experiences in Poland. Indeed, in spite of its myriad distancing devices, the work achieves what Huyssen (2003: 135) has called a "powerful effect of authentication." That authentication, and even any concern about it, has disappeared in Austerlitz. The loss and confusion of Sebald's character, his helpless meanderings and pointless searches, and the beautiful prose that conveys absence and an objectless and thus endless melancholia, all this, combined with blurry, hard-to-make-out photographic images, speaks somehow to a generation marked by a history to which they have lost even the distant and now barely "living connection" to which Maus uncompromisingly clings.

While Maus begins as a familial story, Austerlitz only becomes so halfway through: familiality anchors, individualizes, and reembodies the free-floating disconnected and disorganized feelings of loss and nostalgia that thereby come to attach themselves to more concrete and seemingly authentic images and objects. Still, the world around Sebald's character does not actually become more readable, nor does his connection to the past become more firm, when he finds his way back to a personal and familial history, to Prague, where he was born and where he spent a very few years before being sent to England on the Kindertransport, and to the nurse who raised him and knew his parents.

The images Austerlitz finds, I want to argue, are what Warburg calls "pre-established forms," which amount to no more than impersonal building blocks of affiliative postmemory. "Our concern with history," Austerlitz (2001: 72) says, quoting his boarding school history master André Hilary, "is a concern with preformed images already imprinted on our brains, images at which we keep staring while the truth lies elsewhere, away from it all, somewhere as yet undiscovered." This passage perfectly encapsulates the perils of postmemory and the central point I want to make in this essay. The images already imprinted on our brains, the tropes and structures we bring from the present to the past, hoping to find them there and to have our questions answered, may be screen memories - screens on which we project present or timeless needs and desires and which thus mask other images and other concerns. The familial aspects of postmemory that make it so powerful and problematically open to affiliation contain many of these preformed screen images. What more potent such image than the image of the lost mother and the fantasy of her recovery?

In Maus, the photograph of mother and son, a postwar image embedded in the inserted "Prisoner on the Hell Planet: A Case History," anchors and authenticates the work. As the only photograph in the first volume, it solidifies the mother's material presence even as it records her loss and 
suicide. Maternal recognition and the maternal look are anything but reassuring: in fact, when the artist draws himself wearing a concentration camp uniform, he signals his complete transposition into his parents' history and his incorporation of their trauma in Auschwitz activated by the trauma of his mother's suicide. ${ }^{14}$ Still, there is no doubt in the work that this is a photo of Anja and Art Spiegelman. Taken in 1958, it shows not the war but its aftermath. Through the angle at which it is drawn, it breaks out of the page, acting as a link between the comics medium and the viewer, drawing the viewer into the page and counterbalancing its many distancing devices (the multiple hands holding the page and the photo, the expressionist drawing style that yanks the reader out of the commix style of the rest of the book, and the human forms that challenge the animal fable to which we have become habituated in our reading, to name but a few). The maternal image and the "Prisoner" insert solidify the familiality of Maus's postmemorial transmission and individualize the story. At the same time, Anja's suicide in the late 1960 s can also be seen as a product of her postAuschwitz historical moment - a moment at which other Holocaust survivors like Paul Celan and, a few years later, Jean Améry also committed suicide.

The two "maternal" images in Austerlitz function quite differently: rather than authenticating, they blur and relativize truth and reference. After following his mother's deportation to Terezín, Austerlitz is desperate to find more concrete traces of her presence there. He visits the town, walks its streets, searches the museum for traces, and finally settles on the Nazi propaganda film The Führer Gives a City to the feres as the last possible source in which he might find a visual image of his mother. His fantasies revolve around the extraordinary events of the Red Cross inspection of Terezín, in which inmates were forced to participate in performances of normalcy and well-being that were then filmed for propaganda purposes:

I imagined seeing her walking down the street in a summer dress and lightweight gabardine coat, said Austerlitz: among a group of ghetto residents out for a stroll, she alone seemed to make straight for me, coming closer with every step, until at last I thought I could sense her stepping out of the frame and passing over into me. (Ibid.: 245)

The fantasy is so strong that, against all odds, Austerlitz does succeed in finding in the film an image of a woman who, he believes (or hopes), might be his mother. The film to which he finds access in a Berlin archive is only a fourteen-minute version of the Nazi documentary, and after watching it

14. On transposition, see Kestenberg 1982. 
repeatedly, he concludes that his mother does not appear in it. But he does not give up: he has a slow-motion hour-long copy made of the excerpt, and he watches it over and over, discovering new things in it but marveling also at the distortions of sound and image that now mark it. In the very background of one of the sequences contained in these distorted slow-motion fragments of a propaganda film of fake performances of normalcy, Austerlitz does eventually glimpse a woman who reminds him of his image of his mother. In the audience at a concert,

set a little way back and close to the upper edge of the frame, the face of a young woman appears, barely emerging from the back shadows around it. ... She looks, so I tell myself as I watch, just as I imagined the singer Agáta from my faint memories and the few other clues to her appearance that I now have, and I gaze and gaze again at that face which seems to me both strange and familiar, said Austerlitz. (Ibid.: 251)

Far from the fantasy of recognition and embrace that Austerlitz spun out for the novel's narrator - "she alone seemed to make straight for me, coming closer with every step, until at last I could sense her stepping out of the frame" - the woman's face is partially covered by the time indicator showing only $4 / 100$ of a second during which it appears on screen. In the foreground of the image, the face of a gray-haired man takes up most of the space, blocking the backgrounded woman from view.

In the novel, this picture can at best become a measure of the character's desire for his mother's face. It tells us as little about her and how she might have looked, what she lived through, as the photo of an anonymous actress Austerlitz finds in the theater archives in Prague. His impression that this found image also looks like Agáta is corroborated by Vera, who nods, but the link to truth or authentication remains equally tentative and tenuous. Austerlitz hands both images over to the narrator along with his story, as though for protection and dissemination. What, with this precious image, is the narrator actually receiving? Even for the familial second (or 1.5) generation, pictures are no more than spaces of projection, approximation, and affiliation; they have retained no more than an aura of indexicality. For more distant affiliative descendants, their referential link to a sought-after past is ever more questionable. The images Austerlitz finds, moreover, are, in themselves, products of performances - his mother was an actress before the war, and what is more, in the propaganda film in Terezín, all inmates were forced to play a part that would further the workings of the Nazi death machine. Unlike the picture of mother and son in Maus, which was probably taken by the father, the presumed image of Agáta in the film inscribes the gaze of the perpetrator and thus also the genocidal intentions 
of the Nazi death machine and the lies on which it was based (see Hirsch 2001). The numbers in the corner, of course, recall the Auschwitz numbers and thus anticipate the fate of the Terezin prisoners. They overpower the figures who shrink beneath the fate that awaits them. But who are these figures? Has Austerlitz, has the narrator found what they were seeking?

Austerlitz's description of the film still throws ever more doubt on the process of postmemorial looking. He (2001: 251) focuses on one telling detail: "Around her neck, said Austerlitz, she is wearing a three-stringed and delicately draped necklace which scarcely stands out from her dark, high necked dress, and there is, I think, a white flower in her hair." The necklace, I believe, connects this image - whether deliberately or not - to another important maternal photograph, that of Barthes's mother in Camera Lucida, perhaps the image exemplifying the trope of maternal loss and longing and the son's affiliative look that attempt to suture an unbridgeable distance.

The necklace appears in Barthes's discussion of a picture by James van der Zee not so much as a prime example of Barthes's notion of the punctum as detail, and of the affective link between the viewer and the image, but of how the punctum can travel and be displaced from image to image. Barthes (1981: 53) first finds the picture's punctum in the strapped pumps worn by one of the women; a few pages later, when the photograph is no longer in front of him or of us, he realizes that "the real punctum was the necklace she was wearing; for (no doubt) it was this same necklace (a slender ribbon of braided gold) which I had seen worn by someone in my own family." In a brilliant reading of Barthes's notion of the punctum, Margaret Olin (2002) takes us back to the initial image to expose Barthes's glaring mistake: the women in van der Zee's image wear strings of pearls and not "slender ribbons of braided gold." The slender ribbon of braided gold, she argues, was transposed from one of his own family pictures, which Barthes had reproduced in his Roland Barthes by Roland Barthes (1977) and entitled "the two grandmothers." 15

Olin uses this example to call into question the very existence of the famous winter garden photo of Barthes's mother in Camera Lucida, showing how some of the details in his description might have been drawn from another text, Walter Benjamin's (1980: 206) description of a photograph of the six-year-old Kafka in a "winter garden landscape." The mother's

15. But Olin is also mistaken, as Nancy K. Miller (2006) pointed out to me in conversation: the English translation of Camera Lucida leaves out the more specific description in the French, where the necklace is described as being "au ras du cou" rather than long and hanging down as in the image of the "two grandmothers." 
picture may instead be one that is indeed reproduced in Camera Lucida, La souche (The Stock) (Barthes 1981: 104). These displacements and intertextualities, which Olin (2002: 112) delineates in fascinating detail, lead her usefully and yet dangerously to redefine the photograph's indexicality: "The fact that something was in front of the camera matters; what that something was does not. . . What matters is displaced," she provocatively states. In her conclusion (ibid.: 115), she proposes that the relationship between the photograph and its beholder be described as a "performative index" or an "index of identification," shaped by the reality of the viewer's needs and desires rather than by the subject's actual "having-been-there" (see also Hirsch and Spitzer 2006 and Doane 2007).

I believe that the maternal image in Austerlitz can be inserted into the intertextual chain Olin identifies, especially since, amazingly, Austerlitz also makes a mistake about the necklace which, in the photo, only has two strings and not three as he claims. To call reference into question in the context not just of death, as with Barthes's mother, but of extermination, as with Austerlitz, may be more provocative still, but this is, indeed, how photographs function in this novel. As Austerlitz shows, the index of postmemory (as opposed to memory) is the performative index, shaped more and more by affect, need, and desire as time and distance attenuate the links to authenticity and "truth." Familial and, indeed, feminine tropes rebuild and reembody a connection that is disappearing, and thus gender becomes a powerful idiom of remembrance in the face of detachment and forgetting.

In her feminist reflections on the transmission of Holocaust memory, Claire Kahane (2000: 163) writes: "Literary representation of the Holocaust attempts a textual mimesis of trauma through tropes that most potently capture, and elicit in the reader ... primal affects contiguous with the traumatic event." Kahane illustrates her point through a critical analysis of the trope of maternal loss and mother-child separation, arguing that trauma at its most fundamental has been defined as a break in the maternal object relation (ibid.). Kahane disagrees that the trauma of the Holocaust can be reduced to one particular psychic structure, and thus she urges us to remain skeptical of the ubiquity of the figure of maternal loss in Holocaust representation. She asks: "Doesn't the focus on that relation in traumatic narratives itself become a kind of screen, a cover-up for the terror of confronting the nihilistic implications of the Holocaust?" (ibid.: 164).

As the foregoing discussion shows, I want to join Kahane's call that we scrutinize carefully the dominant tropes of Holocaust representation, such as the figure of maternal loss. At the same time, I have argued that the generation of affiliative postmemory needs precisely such familiar and 
familial tropes to rely on. For feminist critics, it is particularly important to perceive and expose the functions of gender as a "pre-formed image" in the act of transmission. The photograph of the mother's face is a "preformed image" at which we stare, while, as Austerlitz (2001: 245) says, "the truth lies elsewhere, somewhere as yet undiscovered." At our generational remove, that elsewhere may never be discovered. Thus the maternal image in Austerlitz provokes us to scrutinize the unraveling link between present and past that defines indexicality as no more than performative.

And yet, for better or worse, one could say that, for the postgeneration, the screens of gender and of familiality and the images that mediate them function analogously to the protective shield of trauma itself: they function as screens that absorb the shock, filter and diffuse the impact of trauma, diminish harm. In forging a protective shield particular to the postgeneration, one could say that, paradoxically, they actually reinforce the living connection between past and present, between the generation of witnesses and survivors and the generation after.

\section{References}

Assmann, Aleida

2006 Der lange Schatten der Vergangenheit: Erinnerungskultur und Geschichtspolitik (Munich: Beck).

Assmann, Jan

1997 Das kulturelle Gedächtnis: Schrift, Erinnerung und politische Identität in früheren Hochkulturen (Munich: Beck).

Baer, Ulrich 2002 Spectral Evidence: The Photography of Trauma (Cambridge: MIT Press).

Bal, Mieke, Jonathan Crewe, and Leo Spitzer, eds. 1998 Acts of Memory: Cultural Recall in the Present (Hanover, NH: University Press of New England).

Barthes, Roland

1977 Roland Barthes by Roland Barthes, translated by Richard Howard (Berkeley: University of California Press).

1981 Camera Lucida: Reflections on Photography, translated by Richard Howard (New York: Hill and Wang).

Benjamin, Walter 1980 "A Short History of Photography," translated by P. Patton, in Classic Essays on Photography, edited by Alan Trachtenberg, 199-216 (New Haven, CT: Yale University Press).

Bennett, Jill 2005 Empathic Vision: Affect, Trauma, and Contemporary Art (Palo Alto, CA: Stanford University Press).

Bos, Pascale 2003 "Positionality and Postmemory in Scholarship on the Holocaust," Women in German Yearbook 19: 50-74.

Bukiet, Melvin, ed. 2002 Nothing Makes You Free: Writings by Descendants of Holocaust Survivors (New York: Norton). 
Chambers, Ross

2004 Untimely Interventions: Aids Writing, Testimonial, and the Rhetoric of Haunting (Ann Arbor:

University of Michigan Press).

Connerton, Paul

1989 How Societies Remember (Cambridge: Cambridge University Press).

Didi-Huberman, Georges

2003a Images malgré tout (Paris: Minuit).

2003b "Artistic Survival: Panofsy vs. Warburg and the Exorcism of Impure Time," Common Knowledge 9 (2): 273-85.

Doane, Mary Ann

2007 "Indexicality: Trace and Sign; Introduction," Differences 18: 1-6.

Epstein, Helen

1979 Children of the Holocaust: Conversations with Sons and Daughters of Survivors (New York: Penguin).

Fine, Ellen

1988 "The Absent Memory: The Act of Writing in Post-Holocaust French Literature," in

Lang 1988: 41-57.

Fleckner, Uwe, and Sarkis

1998 The Treasure Chests of Mnemosyne: Selected Texts on Memory Theory from Plato to Derrida

(Dresden: Verlag der Kunst).

Fresco, Nadine

1984 "Remembering the Unknown," International Review of Psychoanalysis 11: 417-27.

Halbwachs, Maurice

1992 On Collective Memory, edited and translated by Lewis Coser (Chicago: Chicago University Press).

Hartman, Geoffrey H.

1996 The Longest Shadow: In the Aftermath of the Holocaust (Bloomington: Indiana University Press).

Hilberg, Raul

1985 The Destruction of the European Feres, 3 vols. (New York: Holmes and Meier).

Hirsch, Marianne

1992-93 "Family Pictures: Maus, Mourning, and Post-Memory," Discourse 15 (2): 3-29.

1997 Family Frames: Photography, Narrative, and Postmemory (Cambridge, MA: Harvard University Press).

1998 "Projected Memory: Holocaust Photographs in Personal and Public Fantasy," in Bal et al. 1998: 2-23.

2001 "Surviving Images: Holocaust Photographs and the Work of Postmemory," in Visual Culture and the Holocaust, edited by Barbie Zelizer, 146-214 (New Brunswick, NJ: Rutgers University Press).

Hirsch, Marianne, and Leo Spitzer

2006 "What's Wrong with This Picture? Holocaust Photographs in Contemporary Narratives," Fournal of Modern Fewish Studies 5 (2): 229-52.

Hoffman, Eva

2004 After Such Knowledge: Memory, History, and the Legacy of the Holocaust (New York: Public Affairs).

Hornstein, Shelley, and Florence Jacobowitz

2002 Representation and Remembrance: The Holocaust in Art (Bloomington: Indiana University Press).

Horstkotte, Silke

2003 "Literarische Subjektivität und die Figur des Transgernationellen in Marcel Beyers Spione und Rachel Seifferts The Dark Room," in Historisierte Subjekte-Subjektivierte Historie: Zur Verfigbarkeit und Unverfügbarkeit von Geschichte, edited by Stefan Deines, Stephan Jaeger, and Ansgar Nunning, 275-93 (Berlin: de Gruyter). 
Hüppauf, Bernd

1997 "Emptying the Gaze: Framing Violence through the Viewfinder," New German Critique 72: 3-44.

Huyssen, Andreas

2003 Present Pasts: Urban Palimpsests and the Politics of Memory (Stanford, CA: Stanford University Press).

Kahane, Claire

2000 "Dark Mirrors: A Feminist Reflection on Holocaust Narrative and the Maternal Metaphor," in Feminist Consequences: Gender and Culture, edited by Elisabeth Bronfen and Misha Kavka, 161-88 (New York: Columbia University Press).

Kestenberg, Judith 1982 "A Metapsychological Assessment Based on an Analysis of a Survivor's Child," in Generations of the Holocaust, edited by Martin S. Bergman and Milton E. Jucovy, 83-102 (New York: Basic Books).

Landsberg, Alison 2004 Prosthetic Memory: The Transformation of American Remembrance in the Age of Mass Culture (New York: Columbia University Press).

Lang, Berel, ed. 1988 Writing and the Holocaust (New York: Holmes and Meier).

Liss, Andrea 1998 Trespassing through Shadows: Memory, Photography, and the Holocaust (Minneapolis: Minnesota University Press).

Lury, Celia 1998 Prosthetic Culture: Photography, Memory, Identity (London: Routledge).

McGlothlin, Erin Heather 2006 Second-Generation Holocaust Literature: Legacies of Survival and Perpetration (Rochester, NY: Camden House).

Miller, Nancy K. 2006 Conversation with the author, February 23.

Morris, Leslie 2002 "Postmemory, Postmemoir," in Unlikely History: The Changing German-fewish Symbiosis, 1945-2000, edited by Leslie Morris and Jack Zipes, 291-306 (New York: Palgrave).

Olin, Margaret 2002 "Touching Photographs: Roland Barthes's 'Mistaken' Identification," Representations $80(1): 99-118$.

Pollock, Griselda 2005 "Photographing Atrocity: Becoming Iconic." Paper delivered at the "Picturing Atrocity" conference, CUNY Graduate Center, New York, December 9.

Raczymow, Henri 1994 "Memory Shot through with Holes," translated by Alan Astro, Yale French Studies 85: 98-106.

Robin, Régine 2003 La mémoire saturée (Paris: Stock).

Said, Edward W. 1983 The World, the Text, and the Critic (Cambridge, MA: Harvard University Press).

Sebald, W. G. 2001 Austerlitz, translated by Anthea Bell (New York: Modern Library).

Silverman, Kaja 1996 The Threshold of the Visible World (New York: Routledge).

Sontag, Susan 1989 On Photography (New York: Anchor Doubleday). 2003 Regarding the Pain of Others (New York: Farrar, Strauss, and Giroux). 
Spiegelman, Art

1987 Maus: My Father Bleeds History (New York: Pantheon).

2006 [1972] "Portrait of the Artist as a young \%@??! (Installment \#3)," Virginia Quarterly

Review 82: 30-43 (includes "The First Maus," first published in Funny Pages comics in 1972).

Suleiman, Susan

1993 "War Memories: On Autobiographical Reading," New Literary History 24: 563-75.

2002 "The 1.5 Generation: Thinking about Child Survivors and the Holocaust," American Imago 59 (3): 277-96.

Taylor, Diana

2003 The Archive and the Repertoire: Performing Cultural Memory in the Americas (Durham, NC:

Duke University Press).

van Alphen, Ernst

2005 Art in Mind: How Contemporary Images Shape Thought (Chicago: Chicago University Press).

2006 "Second-Generation Testimony, the Transmission of Trauma, and Postmemory,"

Poetics Today 27: 473-88.

Weigel, Sigrid

2002 "'Generation' as a Symbolic Form: On the Genealogical Discourse of Memory since

1945," Germanic Review 77 (4): 264-77.

Weissman, Gary

2004 Fantasies of Witnessing: Postwar Efforts to Experience the Holocaust (Ithaca, NY: Cornell

University Press).

Young, James

1997 "Toward a Received History of the Holocaust," History and Theory 36 (4): 21-43.

Zeitlin, Froma

1998 "The Vicarious Witness: Belated Memory and Authorial Presence in Recent Holo-

caust Literature," History and Memory 10: 5-42.

Zelizer, Barbie

1998 Remembering to Forget: Holocaust Memory through the Camera's Eye (Chicago: University of

Chicago Press). 